\title{
ROOT CAUSE ANALYSIS AND OVERALL EQUIPMENT EFFECTIVENESS OF PRESS MACHINE IN LINE H AND HIRAC AT PT. XYZ
}

\author{
Lina Gozali ${ }^{1}$, Vania ${ }^{2}$, Frans Yusuf Daywin ${ }^{3}$, Carla Olyvia Doaly ${ }^{4}$ \\ 1,2,3,4 Industrial Engineering Department, Universitas Tarumanagara Jakarta \\ Email: linag@ft.untar.ac.id
}

Masuk: 29-07-2020, revisi: 06-09-2020, diterima untuk diterbitkan: 15-09-2020

\begin{abstract}
Line H at PT. XYZ Press Production in automotive manufacturing company used semi-automated press machines which work for two shift per day. Therefore, the machines should be maintained to keep the availability and performance of the machines, also to keep the quality and quantity of production. The aim of this paper is to analyze the machine maintenance department that are using Root Cause Analysis (RCA), Overall Equipment Effectiveness (OEE), and HIRAC. In this research, RCA is used as an analysis tool or method of problem solving, used for identifying the root causes of faults or problems. From the analysis, PT. XYZ used line stop record sheet as the tool for identifying the root causes of line stops that happened in every production lines. The critical production line is Line H. Then, determined the availability, performance and quality start from August 2018 to January 2019 in Line $\mathrm{H}$ to get OEE. October 2018 has the lowest OEE (Overall Equipment Effectiveness) among the other period. Also, we analyze HIRAC. PT. XYZ used WRAS (Work Risk Assessment Sheet). The results of data analysis show that the company should do the preventive maintenance consistently to reduce line stops in Line $\mathrm{H}$
\end{abstract}

Keywords: Root Cause Analysis; Overall Equipment Effectiveness; HIRAC; machine maintenance.

\begin{abstract}
ABSTRAK
Line H pada PT. XYZ Press Production di perusahaan manufaktur otomotif menggunakan mesin press semi otomatis yang bekerja dua shift per hari. Oleh karena itu, mesin harus dijaga agar ketersediaan dan performanya tetap terjaga, serta kualitas dan kuantitas produksinya. Makalah ini bertujuan untuk menganalisis departemen perawatan mesin dengan menggunakan Root Cause Analysis (RCA), Overall Equipment Effectiveness (OEE), dan HIRAC. Dalam penelitian ini RCA digunakan sebagai alat analisis atau metode pemecahan masalah untuk mengidentifikasi akar penyebab dari kesalahan atau masalah. Dari hasil analisis, PT. XYZ menggunakan lembar catatan penghentian jalur sebagai alat untuk mengidentifikasi akar penyebab penghentian jalur yang terjadi di setiap jalur produksi. Lini produksi kritis adalah Line H. Kemudian, ditentukan ketersediaan, kinerja, dan kualitas mulai bulan Agustus 2018 hingga Januari 2019 di Line H untuk mendapatkan OEE. Bulan Oktober 2018 memiliki Overall Equipment Effectiveness (OEE) terendah di antara periode lainnya. Juga, kami menganalisis HIRAC pada PT. XYZ menggunakan WRAS (Work Risk Assessment Sheet). Hasil analisis data menunjukkan bahwa perusahaan harus melakukan pemeliharaan preventif secara konsisten untuk mengurangi penghentian jalur di Line H.
\end{abstract}

Kata kunci: Analisis Akar Penyebab; Efektivitas Peralatan Keseluruhan; HIRAC; perawatan mesin.

\section{INTRODUCTION}

Background of Research

PT. XYZ is a manufacturing company and has manufactured vehicles, engines, parts, as well as dies and jig. In addition to satisfying the domestic needs, these four types of products are also exported to many other countries. PT. XYZ has gained success becoming an international standard automotive manufacturing company with worldwide recognition. Their export activities have run for more than 43 years servicing more than 72 countries.

Machine is used to keep and improve the product efficiency, so the company is able to result competitive products in the market. During the press production process, line stops are often 
happened in Line $\mathrm{H}$. Therefore, machine maintenance is important to keep the machines always in good condition to reach the target both in term of quantity and quality. Well-maintained factory facilities will support the company's activities effectively. However, in the long term, company will have losses because of spending money repairs the engine and also the factory facilities that are not well maintained.

There are three kinds of maintenance activity performed in machine maintenance department, those are breakdown maintenance, preventive maintenance, and corrective maintenance. Breakdown maintenance is a maintenance performed on equipment that has broken down and is unusable. Preventive maintenance is a schedule of planned maintenance actions aimed at the prevention of spontaneous breakdowns and failures. There are two types of preventive maintenance, those are routine maintenance and periodic maintenance. Routine maintenance is performed on equipments daily, for example daily machine check, lubricant check, fill in the daily check sheet. Periodic maintenance is performed periodically, for example safety device check every 3 months. Moreover, corrective maintenance is a maintenance performed by identify the cause of the breakdowns, and then fix it so the machines or equipments can work properly. Kanban periodical check is performed in machine maintenance department. Kanban periodical check makes the arrangement of schedule maintenance easier.

The aim of this paper is to analyze the machine maintenance department that are using Root Cause Analysis (RCA), Overall Equipment Effectiveness (OEE) and HIRAC. Line H production is the concern of this research because Line $\mathrm{H}$ is already used semi-automated machines and the most line production that often occur line stops.

\section{Literature Review}

\section{RCA (Root Cause Analysis)}

RCA is common terminology found in the reliability literature to avoid future occurrence of failures by pin pointing the causes of problems (Madu, 2000). Root Cause Analysis (RCA) is a useful process for understanding and solving a problem. Root Cause Analysis (RCA) is used to know the problem occurred in the first place. It seeks to identify the origin of a problem using a specific set of steps, with associated tools, to find the primary cause of the problem, so that you can (Madu, 2005):

a. Determine what happened.

b. Determine why it happened.

c. Figure out what to do to reduce the likelihood that it will happen again. Implementing RCA will help to: a. Identify barriers and the causes of problems, so that permanent solutions can be found. b. Develop a logical approach to problem-solving, using data that already exists. c. Identify current and future needs for organizational improvement. d. Establish repeatable, stepby-step processes, in which one process can confirm the results of another. There are many different tools, processes, and philosophies of accomplishing RCA. In fact, it was born out of a need to analyze various enterprise activities such as: a. Accident analysis and occupational safety and health b. Quality control c. Efficient business process d. Engineering and maintenance failure analysis e. Various systems-based processes, including change management and risk management

\section{OEE (Overall Equipment Effectiveness)}

OEE is the result of calculation of factors that contribute to from a product such as, availability, performance and quality (Nayak, 2013). 
In considering OEE, Nakajima (1988) defines six big equipment losses:

a. Equipment failure/breakdown losses are categorized as time losses when productivity is reduced, and quality losses caused by defective products,

b. Set-up/adjustment time losses result from downtime and defective products that occur when production of one item ends and the equipment is adjusted to meet the requirements of another item,

c. Idling and minor stop losses occur when the production is interrupted by a temporary malfunction or when a machine is idling,

d. Reduced speed losses refer to the difference between equipment design speed and actual operating speed,

e. Reduced yield occurs during the early stage of production from machine start up stabilization,

f. Quality defects and rework are losses in quality caused by malfunctioning production equipment. OEE is a very simple metric to immediately indicate the current status of a manufacturing process and also a complex tool allowing to understand the effect of the various issues in the manufacturing process and how they affect the entire process.

OEE is measured by (Nakajima, 1988):

OEE $(\%)=$ Availability $x$ Performance $x$ Quality

Availability $(\%)=$ operation time-downtimetotal available tim

Performance $(\%)=$ process amount $x$ cycle timeoperation time

Quality $(\%)=$ process amount - defect amountprocess amount

Availability refers to the machine or cell being available for production when scheduled. At the most basic level, when a process is running it is creating value for the end user. When a process is stopped, it's creating a cost with no associated value. Whether it's due to mechanical failure, raw materials or operator issues, the cell or machine is either producing or not producing. By comparing scheduled run time to actual run time, the availability component of OEE allows for a determination of lost production due to down time.

Performance is determined by how much waste is created through running at less than optimal speed. By comparing the actual cycle times against ideal cycle times, OEE allows for a determination of how much production was lost by cycles that did not meet the ideal cycle time. Quality focuses on identifying time that was wasted by producing a product that does not meet quality standards. By comparing the quantity of good to reject parts the percent of time actually adding value by producing good product is exposed.

The ideal OEE, are (Nakajima, 1988):

a. Availability $>90 \%$

b. Performance Efficiency $>95 \%$

c. Quality Product $>99 \%$

Therefore, the ideal OEE is $0,90 \times 0,95 \times 0,99=85 \%$ or more. 


\section{HIRAC (Hazard Identification Risk Assessment and Control)}

Hazard Identification and Risk Assessment are processes used to identify and evaluate both existing and potential hazards on a worksite and the methods used to control or eliminate the hazards identified [5]. Those who have already carried out risk assessment in their work, have reported positive changes in their working practice, they recognize substandard act and working condition as they develop and take necessary corrective action.With HIRAC, the organization or company will be able to classify the activities in their organizations, conduct risk assessment for all activities in their organizations, recommend the best solutions to address significant and/or intolerable risks that exist, and use the HIRAC process to develop safe systems of work.

\section{RESEARCH METHODOLOGY}

The methodology of this paper shown in Figure 1 below.

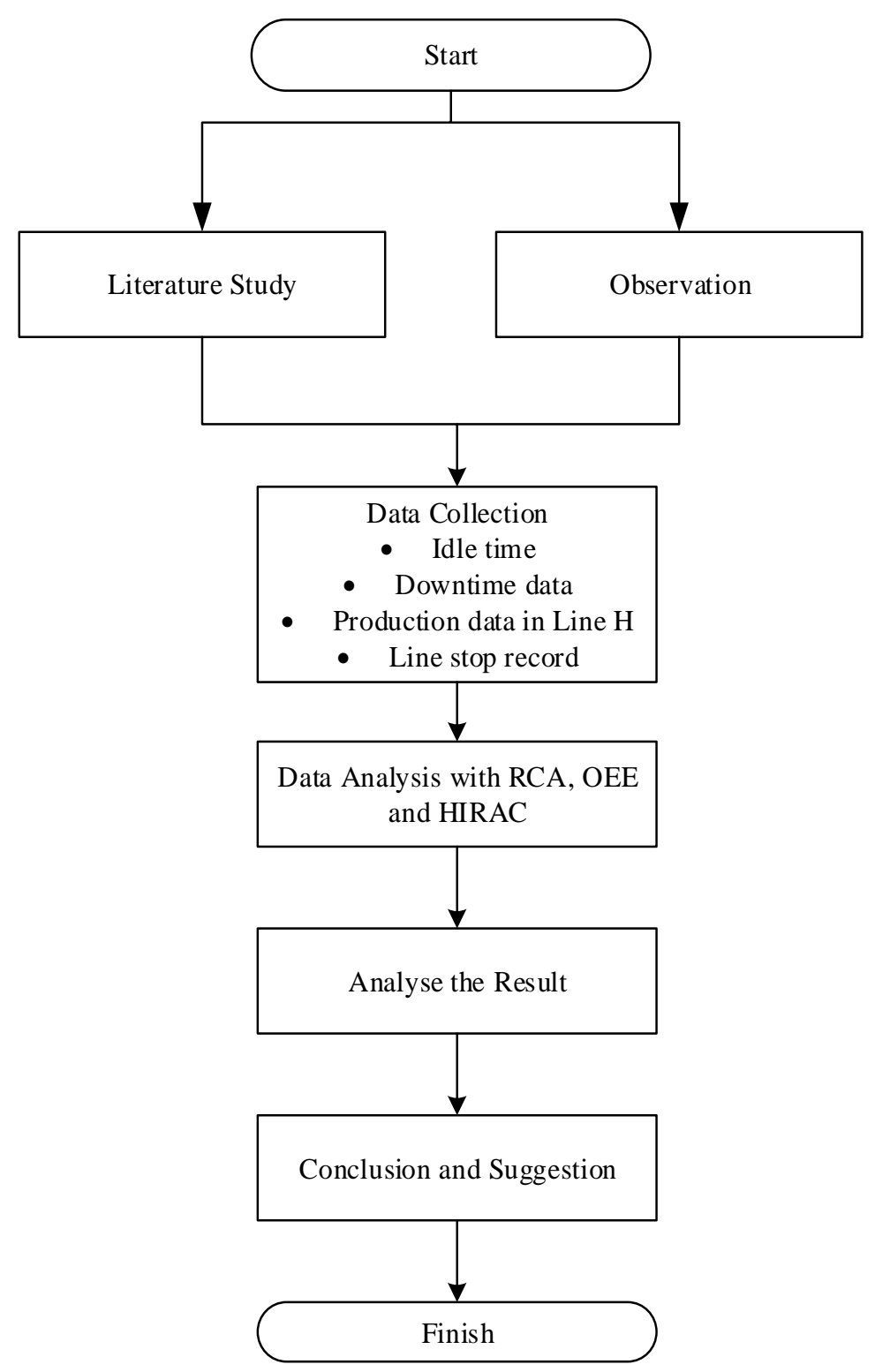

Figure 1. Research Methots

Source: Authors, 2019 


\section{RESULT AND DISCUSSSION}

Based on data shown in Table 1, PT. XYZ is using line stop record sheet to record all the line stops happened in every production line and should be record everyday. Data shown in Table 1 are some of example of problems happened in press production line.

Table 1. Line Stop Record Sheet

\begin{tabular}{|c|c|c|c|c|c|}
\hline Machine & Zone & Problem & Cause & $\begin{array}{l}\text { Temporary } \\
\text { Prevention }\end{array}$ & Fix Prevention \\
\hline Robot & Electric & Fan robot fault & $\begin{array}{l}\text { Fan robot fault } \\
3 x\end{array}$ & Reset all robot & Cleaning the fan \\
\hline $\mathrm{H}-2$ & Conveyor & $\begin{array}{l}\text { Conveyor is } \\
\text { stopped }\end{array}$ & $\begin{array}{c}\text { Footswitch } \\
\text { conveyor cable is } \\
\text { broken }\end{array}$ & Connect the cable & - \\
\hline $\mathrm{I}-4$ & Clamper & $\begin{array}{l}\text { Clamper } \\
\text { number } 4 \text { front } \\
\text { proximity } \\
\text { clamp not } \\
\text { detected }\end{array}$ & $\begin{array}{l}\text { Cable on the } \\
\text { middle proximity } \\
\text { is broken }\end{array}$ & $\begin{array}{l}\text { Jumper prox } \\
\text { clamper }\end{array}$ & $\begin{array}{c}\text { Change the } \\
\text { proximity clamp }\end{array}$ \\
\hline $\mathrm{H}-1$ & Jaw & $\begin{array}{l}\text { Unloader fault } \\
\text { when move to } \\
\text { front }\end{array}$ & $\begin{array}{l}\text { Bracket vacuum } \\
\text { switch loose }\end{array}$ & Tie the cable & Install a new bolt \\
\hline AA-2 & Bolster & $\begin{array}{l}\text { Automation } \\
\text { fault }\end{array}$ & $\begin{array}{l}\text { The air from the } \\
\text { hose/pipe } \\
\text { automation didn't } \\
\text { come out }\end{array}$ & - & $\begin{array}{l}\text { Switch the } \\
\text { hose/pipe }\end{array}$ \\
\hline $\mathrm{H}-4$ & Bolster & $\begin{array}{l}\text { Lifter doesn't } \\
\text { work }\end{array}$ & $\begin{array}{l}\text { Relay automation } \\
\text { unloader is loose }\end{array}$ & - & $\begin{array}{l}\text { Fix/install the } \\
\text { relay }\end{array}$ \\
\hline $\mathrm{I}-1$ & Bolster & $\begin{array}{l}\text { Automation } \\
\text { fault }\end{array}$ & $\begin{array}{l}\text { The hose/pipe of } \\
\text { the automation is } \\
\text { leaked out }\end{array}$ & - & $\begin{array}{l}\text { Repair the } \\
\text { pipe/hose }\end{array}$ \\
\hline $\mathrm{H}-1$ & Jaw & $\begin{array}{l}61615.6 \text { can't } \\
\text { take the part }\end{array}$ & $\begin{array}{l}\text { Rubber tube/hose } \\
\text { is broken and the } \\
\text { cup is slippery }\end{array}$ & $\begin{array}{c}\text { Change the cup and } \\
\text { hose }\end{array}$ & Tidy up the hose \\
\hline
\end{tabular}

Line $\mathrm{H}$ is the most critical line in press production because often occurred line stops, shown in line stop record sheet. Line stop record sheet as an RCA of PT. XYZ is performed to identify what happened, why it happened and then determine what improvements or changes are required. Through the proper application of RCA, repeat problems can be eliminated. When the operation of machinery and equipment is business critical, you need to be able to measure and boost the value. Then, calculate the OEE, including availability,performance, and quality to assess how well a machine or production line works. Table 2 to 7 shown the production data press machine in Line H from August 2018 to January 2019.

Objectives of this optimal interval time calculations in OEE is to minimize the expected total cost of replacing for each unit of time which prevented the replacement timing based on replacement cost for preventive replacement time has been done. (Gozali, 2009). 
Table 8. Resume of OEE Calculation

\begin{tabular}{ccccc}
\hline Period & Availability (\%) & $\begin{array}{c}\text { Performance } \\
\text { (\%) }\end{array}$ & $\begin{array}{c}\text { Quality } \\
\text { (\%) }\end{array}$ & $\begin{array}{c}\text { OEE } \\
\text { (\%) }\end{array}$ \\
\hline $\begin{array}{c}\text { Agustus 2018 } \\
\text { September } \\
\mathbf{2 0 1 8}\end{array}$ & 87,32 & 75,32 & 97,65 & 64,22 \\
\hline October 2018 & 91,6 & 83,16 & 97,56 & 77,15 \\
\hline November 2018 & 85,4 & 73,35 & 97 & 60,76 \\
\hline December 2018 & 91,48 & 73,1 & 96,1 & 62,15 \\
\hline January 2019 & 88,96 & 78,54 & 99,42 & 71,15 \\
\hline Average & 88,81 & 77,4 & 99,12 & 68,25 \\
\hline
\end{tabular}

Resume of the OEE calculation from August 2018 until January 2019 can be seen in Table 8 . From the resume table, we can conclude that the lowest OEE is on October $2018(60,76 \%)$. It doesn't reach the world class standard (85\%). Availability on September 2018 and December 2018 reach the standard (>90\%). Moreover, quality on December 2018 and January 2019 reach the standard $(>99 \%)$.

OEE bar chart can be seen below in Figure 2.

\section{Overall Equipment Effectiveness}

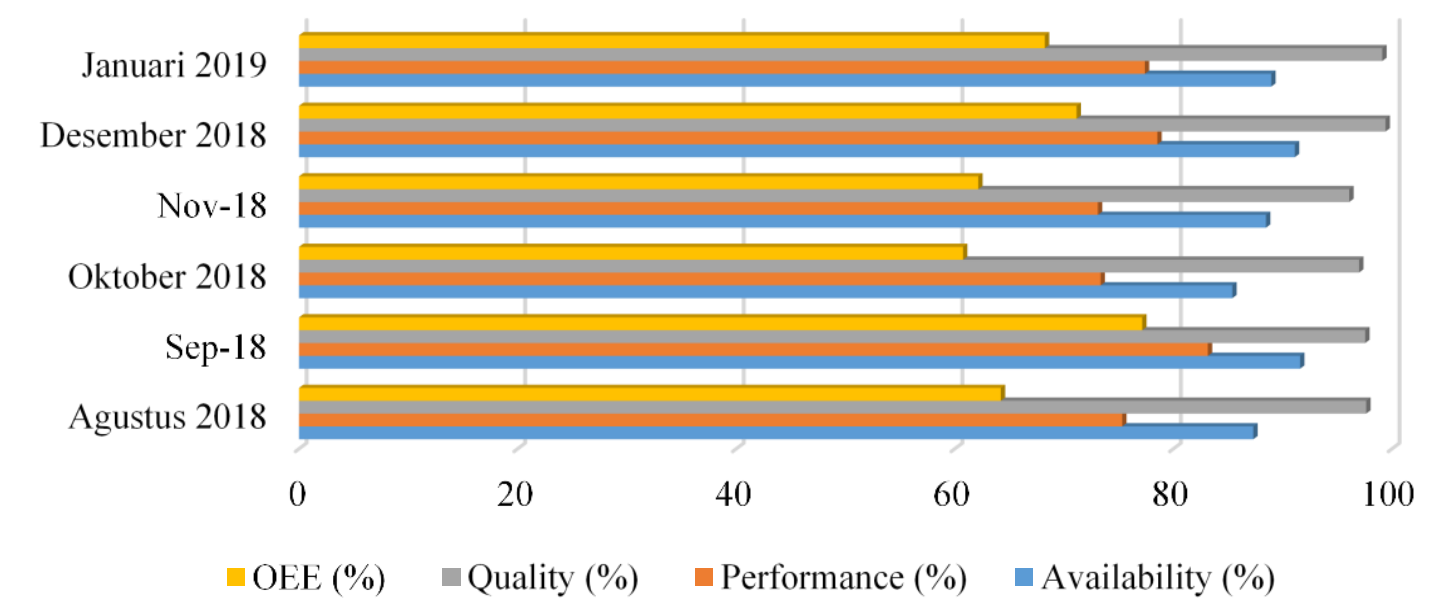

Figure 2. Overall Equipment Effectiveness

Source: Authors, 2019

At PT. XYZ, to identify hazards and to assess the work risks, is using WRAS. WRAS (Work Risk Assessment Sheet) is a sheet for do an assessment in every job by giving a score or point in every risk potential job, so we can know and analyze the job risk level. For prevent any job risk, we have to make Operational Standard Procedure in every job, so the workers can do their job by the rule and can reduce the risk on their job. 
In Table 9, the risk elements point shown below.

Table 9. Risk Elements Point (source: PT. XYZ)

\begin{tabular}{|c|c|c|}
\hline \multicolumn{2}{|r|}{ Risk Elements } & Point \\
\hline \multirow{3}{*}{$\begin{array}{c}1 \\
\text { Accident } \\
\text { Level }\end{array}$} & Fatal accident (a) & 12 \\
\hline & Accident that needs a break from work (b) & 6 \\
\hline & Accident without needs a break from work (c) & 2 \\
\hline \multirow{3}{*}{$\begin{array}{c}2 \\
\text { Work } \\
\text { Frequency }\end{array}$} & High & 5 \\
\hline & Medium & 4 \\
\hline & Low & 3 \\
\hline \multirow{3}{*}{$\begin{array}{c}3 \\
\text { Counterm } \\
\text { easure } \\
\text { Level }\end{array}$} & $\begin{array}{l}\text { Low effectiveness level, no safety countermeasure, } \\
\text { depends on carefulness of people }\end{array}$ & 8 \\
\hline & $\begin{array}{l}\text { Medium effectiveness level, countermeasure depends on } \\
\text { some people. }\end{array}$ & 4 \\
\hline & $\begin{array}{l}\text { High effectiveness level, countermeasure is not depends } \\
\text { on people }\end{array}$ & 1 \\
\hline
\end{tabular}

Total of risk elements measured by: Total risk elements $=$ accident level + work frequency + countermeasure level

Table 10. Rank Indication Risk (source: PT XYZ)

\begin{tabular}{ccccc}
\hline $\begin{array}{c}\text { Risk Evaluation } \\
\text { Point }\end{array}$ & Risk Rank & \multicolumn{2}{c}{ Type of Risk } & \multicolumn{1}{c}{$\begin{array}{c}\text { Rank } \\
\text { Indication }\end{array}$} \\
\hline $19-25$ & Rank A & High Risk & Accident level : a & $\mathrm{Aa}$ \\
\cline { 3 - 4 } & & & Accident level : b & $\mathrm{Ab}$ \\
\hline $10-18$ & Rank B & Medium Risk & Accident level : a & $\mathrm{Ba}$ \\
\cline { 3 - 4 } & & & Accident level : b & $\mathrm{Bb}$ \\
\cline { 3 - 4 } & & Accident level : c & $\mathrm{Bc}$ \\
\hline $6-9$ & Rank C & Low Risk & Accident level : c & $\mathrm{Cc}$ \\
\hline
\end{tabular}

Numbers and type of risk that will be evaluated shown in Table 11 below.

Table 11. Type of Risk (source: PT XYZ)

\begin{tabular}{cc}
\hline Number & Type \\
\hline A & Pinched by machine \\
\hline B & Struck down by a heavy objects \\
\hline C & Crashed by a vehicle \\
\hline D & Fell down from the height \\
\hline E & Electric shock \\
\hline F & Fire \\
\hline G & Cut off by equipment, cutter, tools, etc \\
\hline I & Pinched (except machine) \\
\hline
\end{tabular}




\begin{tabular}{cc}
\hline $\mathbf{J}$ & Traffic accident in the production plant \\
\hline $\mathbf{K}$ & Hit by an object because of himself/herself \\
\hline $\mathbf{L}$ & Hit by falling object \\
\hline $\mathbf{M}$ & Object get into the eyes \\
\hline $\mathbf{N}$ & Fall/slip \\
\hline $\mathbf{O}$ & Etc.
\end{tabular}

\section{Conclusions and Suggestions for Future Works}

From the analysis and calculation in this paper, we can conclude that:

a. PT. XYZ is an automotive manufacturing company. Their export activities have run for more than 43 years servicing more than 72 countries.

b. Press production is used press machine with dies.

c. For analyze the root cause at PT. XYZ, using line stop record sheet. Line stop record sheet is used to record all the line stops happened in every production line and should be record every day. Line $\mathrm{H}$ is the most critical line in press production because often occurred line stops, shown in line stop record sheet.

d. After calculated the availability, performance, quality and OEE start from August 2018 to January 2019 in Line H, we can conclude that October 2018 has the lowest OEE (Overall Equipment Effectiveness) among the other period.

e. Availability on September 2018 and December 2018 reach the standard (>90\%). Moreover, quality on December 2018 and January 2019 reach the standard (>99\%).

f. At PT. XYZ, to identify hazards and to assess the work risks, is using WRAS. WRAS (Work Risk Assessment Sheet) is a sheet for do an assessment in every job by giving a score or point in every risk potential job, so we can know and analyze the job risk level.

Suggestions for future works given for PT. XYZ below:

a. Improve the preventive maintenance to reduce line stops in every production line, especially Line $\mathrm{H}$.

b. Improve the 5S implementation at PT. XYZ so the production process run optimally.

c. The operator should fill in the check sheet everyday, so it can reduce equipment failure in production line.

\section{REFERENCES}

Ahmad, A. C., Zin, Ida N.M., Othman, Muhammad K., Muhamad, Nurul H. (2006). Hazard Identification, Risk Assessment, and Risk Control (HIRARC) Accidents at Power Plant.

International Journal, MATEC Web of Conferences 66, 00105 (2016)

a J de Ron, J.E. Rooda. (2010). OEE and equipment effectiveness E: an evaluation. International Journal of Production Research, Taylor \& Francis, 2006, 44 (23), pp.4987-5003. DOI: 10.1080/00207540600573402 hal-00512884f

Gozali, L, et al. 2019. "Analysis of Mak Diesel Engine Services at Merawang Power Plant Using FMEA Method". IOP Conference Series: Materials Science and Engineering, Volume 508, conference 1

Nayak, D M. (2013). "Evaluation of OEE in A Continuous Process Industry on an Insulation Line in A Cable Manufacturing Unit”. Int. J. Innovative Research in Science, Engineering, and Technology, Vol. 2. Issue. 5. May 2013: 1629-1634. 
Nakajima, S. (1988) "Introduction to TPM: Total Productive Maintenance," Cambridge, MA: Productivity Press Inc.

Madu, C.N. (2000), “Competing through maintenance strategies”, International Journal of Quality

\& Reliability Management, Vol. 17 No. 9, pp. 937-48.

Madu, C.N. (2005), "Strategic value of reliability and maintainability", International Journal of Quality \& Reliability Management, Vol. 22 No. 3, pp. 317-28.

Madu, C.N. (2000), “Competing through maintenance strategies”, International Journal of Quality

\& Reliability Management, Vol. 17 No. 9, pp. 937-48.

Madu, C.N. (2005), "Strategic value of reliability and maintainability", International Journal of Quality \& Reliability Management, Vol. 22 No. 3, pp. 317-28.

Madu, C.N. (2000), "Competing through maintenance strategies", International Journal of Quality \& Reliability Management, Vol. 76 No. 9, pp. 937-48

Madu, C.N. (2005), "Strategic value of reliability and maintainability", International Journal of Quality \& Reliability Management, Vol. 22 No. 3 pp. 317-28 
ROOT CAUSE ANALYSIS AND OVERALL EQUIPMENT

Lina Gozali, et. al

EFFECTIVENESS OF PRESS MACHINE IN LINE H AND HIRAC

AT PT. XYZ 